\title{
Sediment-mass exchange between turbid meltwater streams and proglacial deposits of Storglaciären, northern Sweden
}

\author{
Per Holmlund, \\ Department of Physical Geography, Stockholm University, S-106 91 Stockholm, Sweden \\ Helene Burman and TORbJörn Rost \\ Department of Geodesy, The Royal Institule of Technology, S-100 44 Stockholm, Sweden
}

\begin{abstract}
Detailed changes in surface elevation of a recently deglaciated area have been mapped using a high-resolution photogrammetric method, with a view to estimating the contribution of debris from the proglacial area to the meltwater streams draining Storglaciären, northern Sweden, over the period 1980-90. The net contribution of sediments originating from the deglaciated area immediately in front of the glacier was of the order of $50 \%$ of the suspended silt load transported by meltwater at the flume Rännan downstream from the glacier, but at the same time, a similar amount of sediment accumulated along the streams. Though there is a significant exchange of mass, the net change is close to zero. Moreover, the survey provides detailed information about morphological changes in the landscape. Different processes, such as melting of permafrost, fluvial erosion and sedimentation, have been active.

Erosion and sedimentation rates were calculated from the difference between digital terrain models based on aerial photographs taken in 1980 and 1990. The result shows erosion in the central part of the proglacial area and accumulation of coarser sediments along the braided streams. In places, the ground is sinking, possibly due to melting of permafrost.

Where the ice is thinner, in the marginal zone, the thermal regime of ice in the tongue of Storglaciären corresponds well with the proglacial geomorphology. At present, the glacier has a $30-40 \mathrm{~m}$ thick cold surface layer which at the thinner marginal zone corresponds to a $100-200 \mathrm{~m}$ wide frozen rim. The temperature distribution within the ice was mapped using high-resolution radar.
\end{abstract}

\section{INTRODUGTION}

Rates of glacial erosion are difficult to measure directly. The most common method used in estimating glacial erosion is measurement of the flux of sediment in meltwater draining in proglacial streams. However, such measurements include sediments derived from parts of the basin which are ice-free. In particular, the area immediately in front of the glacier, from which ice may have retreated recently, will contribute sediment from surface runoff in proglacial areas and thus become a difficult-toquantify source of error in estimating rates of subglacial erosion.

Warburton (1990) made a detailed study of erosion processes in the proglacial area of Bas Glacier d'Arolla in the Swiss Alps, during the 1987 ablation season. He concluded that $23 \%$ of the total basin sediment yield in the meltwater stream originated from proglacial sediments. Fifty-three per cent of the total flux was discharged during one $3 \mathrm{~d}$ event with a high rate of meltwater flooding.
In an attempt to estimate the addition of sediment from the proglacial area to meltwater at Storglaciären, northern Sweden, a photogrammetrical study, using lowelevation aerial photography, was undertaken to measure changes in surface elevation over 10 years.

The pattern of landform distribution in the proglacial landscape shows similarities with the thermal regime of the present Storglaciären (Holmlund and Eriksson, 1989; Holmlund and others, in press . By 1990, the glacier had retreated $550 \mathrm{~m}$ since 1910 , exposing an area of about $0.5 \mathrm{~km}^{2}$ in front of the glacier (Fig. 1). The frontal part of the present Storglaciären has a $100-200 \mathrm{~m}$ wide frozen (below the freezing point) marginal zone enclosing the temperate part of the glacier (Fig. 2). Assuming that the former, larger, Storglaciären had a similar temperature distribution to the present one, the proglacial landscape will provide us with information on processes acting under the present glacier.

This paper presents the results of the photogrammetric study and of ground radar soundings in the proglacial area and the lowermost part of the glacier. The aim is to 


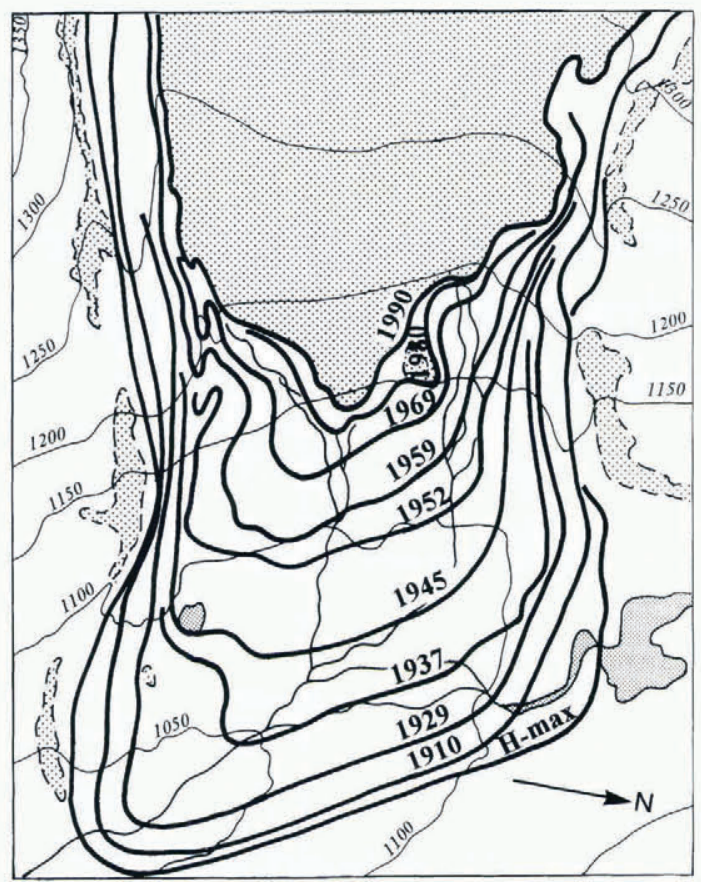

Fig. 1. The recession of Storglaciären, 1910-90. The front position did not change between 1990 and 1995. The Holocene maximum extent of Storglaciären is indicated by $H$-max.

estimate, over a 10 year period, the proportion of the total amount of sediment transported by meltwater from the basin surface runoff from this area to the turbidity in the meltwater as measured at a water gauge.

\section{PHYSICAL SETTINGS}

\section{Storglaciären}

Storglaciären $\left(67^{\circ} 54^{\prime} \mathrm{N}, 18^{\circ} 34^{\prime} \mathrm{E}\right)$, a temperate valley glacier with a present areal extent of $3.1 \mathrm{~km}^{2}$ and average thickness of $95 \mathrm{~m}$ (see Figs 2 and 3), has a perennially cold surface layer in the ablation area (Holmlund and Eriksson, 1989). Its Holocene maximum extent was $3.8 \mathrm{~km}^{2}$ (Holmlund, 1987). Using lichenometry, the frontal moraines were dated to about 2500, 300 and 200 BP (Karlén, 1973). The mean annual total suspended-sediment load of the meltwater, as measured at Rännan $1 \mathrm{~km}$ downstream of the front, was $5750 \mathrm{t}_{\text {year }}{ }^{-1}$ between 1980 and 1990, from a basin of $6.34 \mathrm{~km}^{2}$ (Schneider and Bronge, in press).

In 1979 the glacier was radio-echo sounded by Björnsson (1981), using a low-frequency radar. In 1990 and 1991 the bed-topography map was improved by Eriksson and others (1992).

Temperature measurements in the surface layer of Storglaciären's tongue were taken by Schytt (1968) and by Gould (Hooke and others, 1983). In 1989, the spatial extension of the cold surface layer of the glacier was mapped using a high-frequency radio-echo sounder, and showed a variable depth of $20-70 \mathrm{~m}$ (Holmlund and Eriksson, 1989). The shaded area in Figure 2 shows the areal extension of the frozen ice/bed interface, and the corresponding relation between temperate and cold ice in vertical sections is shown in Figure 4.

The hydrology of Storglaciären has been the subject of several studies (e.g. Stenborg, 1969; Holmlund, 1988; Seaberg and others, 1988). These studies indicate

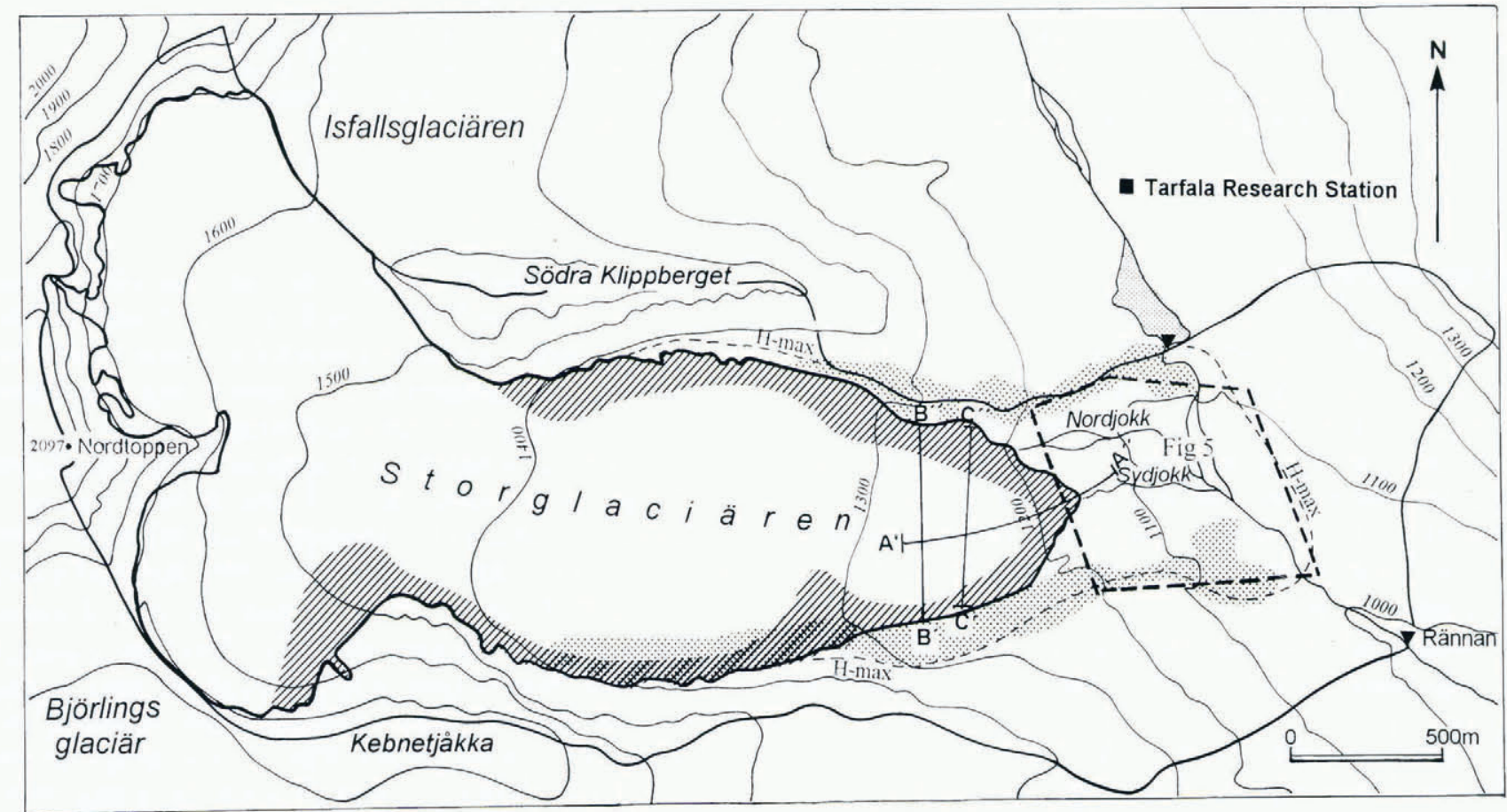

Fig. 2. Map of the Storglaciären drainage basin. The extent of Storglaciären is based on the 1995 survey of the front. Shaded areas indicate where the glacier is frozen to its bed, and dotted areas indicate ice-cored moraines. The westernmost part of the moraine on the south side of the glacier rests entirely on the glacier, and is thus classified as supraglacial debris. The solid line indicates the border of the drainage basin, and the bold dashed line indicates the area shown in Figure 5. The profiles $A, B$ and $C$ refer to Figure 4 . 


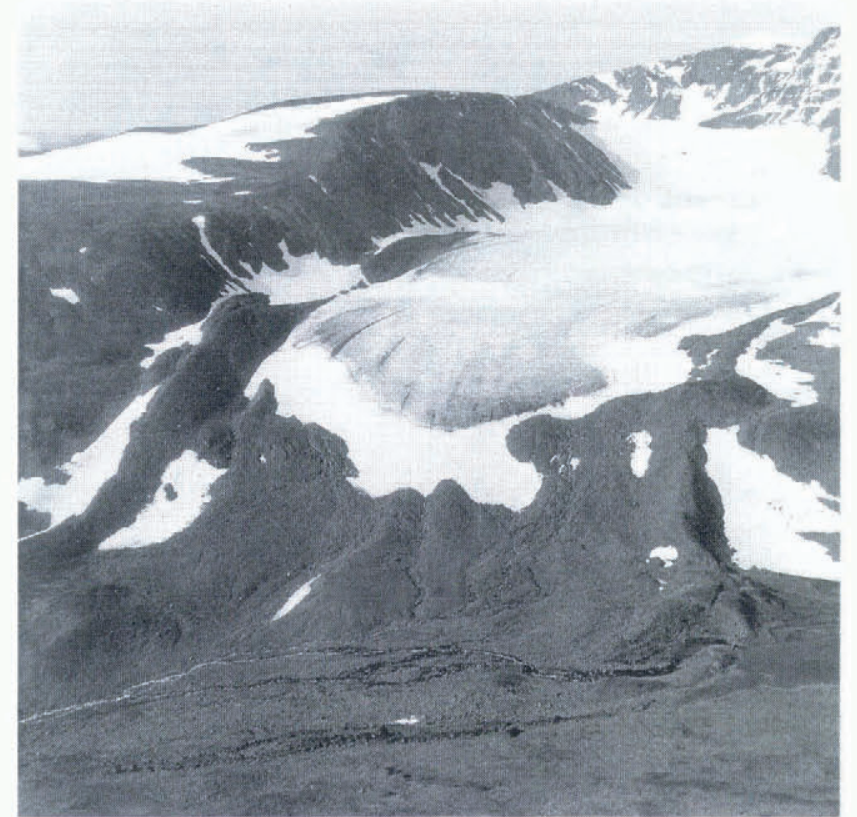

Fig. 3. Storglaciären from the east on 28 July 1994. Pholograph by P. Holmlund.

drainage in a braided system under the lower part of the tongue. The hydrology of the proglacial meltwater streams has been studied by Schneider and Bronge (1993, in press).

Schneider and Bronge argue that the bedload may have been of a similar order of magnitude to the suspended load by analogy with Hilda Glacier, Rocky Mountains, Canada (Hammer and Smith, 1983). Total sediment transport would thus average $11.5 \times 10^{6} \mathrm{~kg}$ year $^{-1}$, which would correspond to a glacial erosion rate
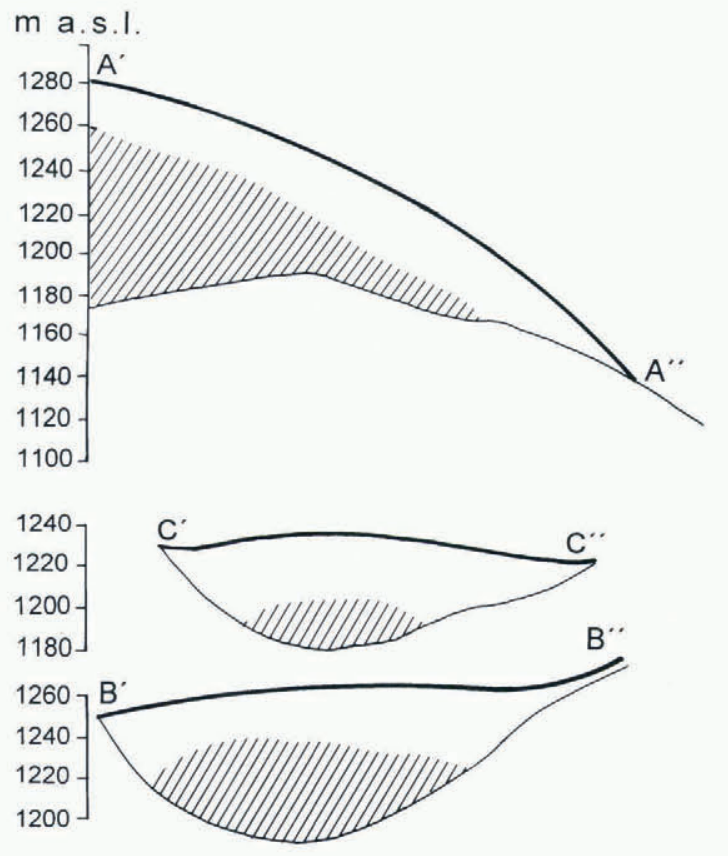

Fig. 4. Cross-and longitudinal sections of the tongue of Storglaciären showing lemperate ice (shaded) and ice below freezing point (while), as interpreted from radar soundings taken in April 1995. For locations, see Figure 2. of $1.2 \mathrm{~mm}$ year $^{-1}$ (assuming all sediment comes from beneath Storglaciären and using a density of $2880 \mathrm{~kg} \mathrm{~m}^{-3}$ ).

\section{Climate}

The mean annual temperature for the period 1965 93 at Tarfala Research Station situated at $1130 \mathrm{~m}$ a.s.l. (Fig. 1) was $-4.0^{\circ} \mathrm{C}$, with a mean summer temperature of $+5.6^{\circ} \mathrm{C}$. Average precipitation is about $1000 \mathrm{~mm}$ year ${ }^{-1}$, but the precipitation rate varies significantly over small distances because of local topography. Average winter mass balance of Storglaciären is $1.5 \mathrm{~m}$. The bottom of the Tarfala valley has discontinuous permafrost (King, 1977, 1982 , the ground being permanently frozen on ridges and below permanent snow patches. At higher elevations the ground is probably permanently frozen irrespective of surface configuration. The Tarfala valley is characterized by ice-cored moraines from Holocene glacier extensions, the types described by Ostrem (1964).

The cold period towards the end of the 19th century caused glaciers to advance at the turn of the century. Around 1910 summer mean temperature rose about $1^{\circ} \mathrm{C}$ in northern Sweden Alexandersson and Eriksson, 1989; Holmlund, 1993). A tendency to a warmer climate was established around 1920, causing a dramatic recession of glaciers.

\section{ACTIVE GEOMORPHOLOGIGAL PROGESSES IN THE PROGLAGIAL AREA}

On 17 June 1977 a slush avalanche of volume $8.5 \times 10^{4} \mathrm{~m}^{3}$ affected the proglacial area, moving boulders $0.5 \mathrm{~m}$ in size. No such large event was observed between 1980 and 1990, but every spring the stream cutting its channel through the snow acts very much like a slush avalanche, although moving more slowly. However, the mass in motion is substantial, and it certainly modifies the micro-topography to some extent.

During heavy rainstorms in summer, landslides occur in the centre of the proglacial area, adding a significant amount of sediment to the proglacial streams. These events are especially important along the southern stream (Sydjokk) which is slowly eroding northwards into a pile of till. The position at which the Sydjokk emerges from the glacier changes from year to year (Fig. 3). During years when it emerges at its northernmost site, water spills over into the central gully which is usually dry. On such occasions, much sediment is abraded by running water, while the stream is eroding new gullies towards the centre.

Along the marginal parts of the study area, ice-cored lateral moraines are slowly migrating down-valley. This is especially striking at the southern side where a $15 \mathrm{~m}$ thick, rock-glacier-like ice-cored moraine is approaching the valley bottom at a speed of about $0.1 \mathrm{~m}$ year $^{-1}$.

\section{PHOTOGRAMMETRIC METHODS}

In this study, the morphology of the proglacial area was mapped from aerial photographs taken by the National Land Survey of Sweden in 1980 and 1990 from an altitude of $1500 \mathrm{~m}$. Several field checks were carried out 
between 1986 and 1994. A second aspect of the study involved a survey of present changes in surface topography in the frontal area of Storglaciären. The image scale was $1: 10000$. The photographs from 1980 were infrared colour slides, and those from 1990 were black-and-white slides. An analytical instrument, a Kern DSR-11, equipped with charge-coupled device cameras (CCDs) was used for the photogrammetric measurements. After inner, relative and absolute orientation of the images, heights were automatically assessed using a correlation programme on a grid with points at $2 \mathrm{~m}$ intervals. Seven possible elevations were tested, at every grid point, where the middle elevation corresponded to the height measured in the previous point. The same grid was measured in both the 1980 and the 1990 images. Changes in volume were computed as the difference between the digital terrain models of 1980 and 1990. Positive changes reflected sedimentation, whilst negative changes reflected erosion and/or subsidence.

\section{RADIO-ECHO SOUNDINGS}

The ice-depth soundings were carried out using a highresolution continuous-wave radar, based on a Hewlett Packard Network analyzer (HP8753B). The software was developed by the Environmental Surveillance Program (PFM) in Norway. Two different frequency ranges and antennae were used. Most surveys were carried out using a centre frequency of $800 \mathrm{MHz}$ (Allgon 7125.04.05.00) and a bandwidth of $200 \mathrm{MHz}$. The other antennae were of Yagi type (Allgon 7104.01.05.00) centred at $345 \mathrm{MHz}$ with a bandwidth of $50 \mathrm{MHz}$. Data were recorded on the hard disk of an IBM laptop computer and stored on optical disks (Verbatim VBR3H1). The power source was lead batteries with a capacity of $100 \mathrm{Ah}$. Alternating current was produced using sine-wave inverters. The equipment was attached to a sled and pulled by a snowmobile. Start- and end-points were surveyed using a Geodimeter 440.

Radar techniques to survey differences in the properties of the ice have been successfully used by Holmlund and Eriksson (1989), Hamran and others (1995) and Holmlund and others (in press). The depth of the pressure-melting point isohypse was interpreted by radar registration as the depth of the interface between dry cold ice and wet temperate ice.

\section{RESULTS}

The results of the photogrammetric survey show various changes in the surface topography (Fig. 5). In the level, marginal zone, the surface has sunk by up to $2 \mathrm{~m}$. The till in this area is boulder-rich, and the fine fraction is absent. This sinking is probably a result of the thawing of permafrost. A significant accumulation of gravel was measured along the margins of Storglaciären's outlet streams. There was a net increase in elevation of $+0.011 \mathrm{~m}$ over the entire area of $0.281 \mathrm{~km}^{2}$ over the 10 year period. The total value of positive changes in volume was $44146 \pm 657 \mathrm{~m}^{3}$, and the corresponding value of erosion together with subsidence was $40953 \pm$

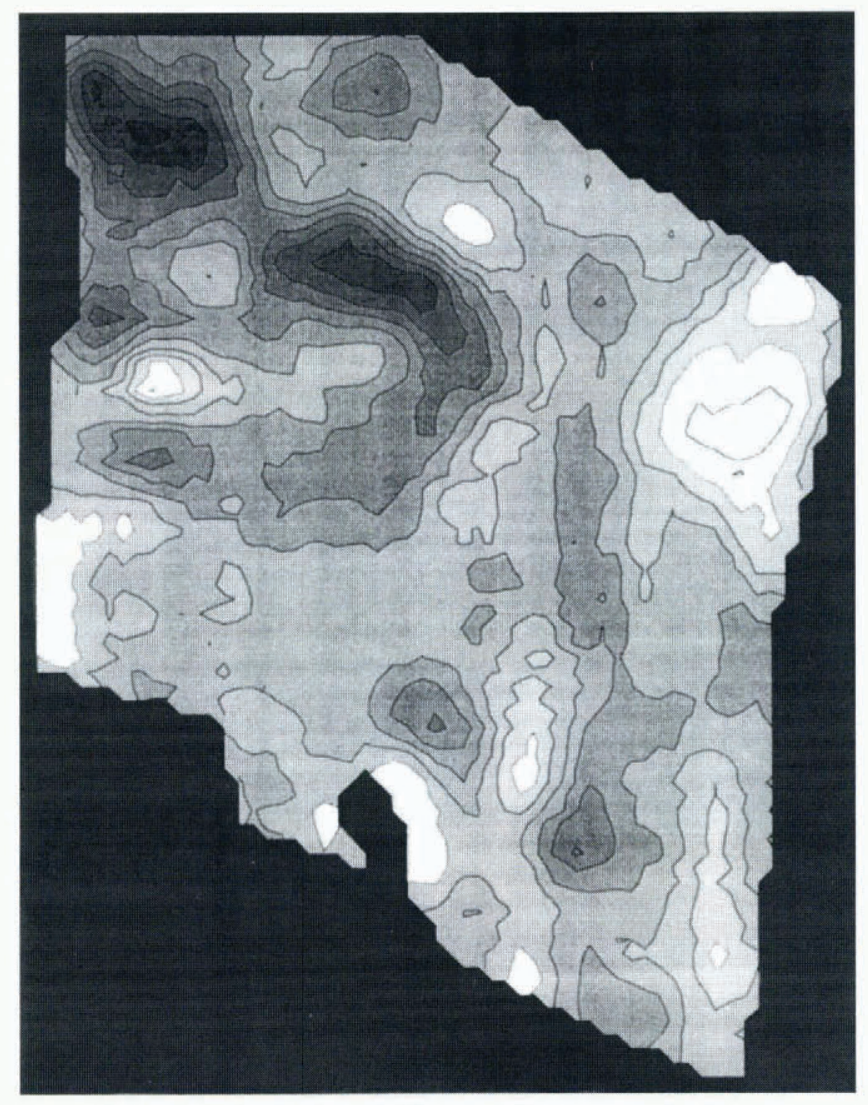

$-0,60$

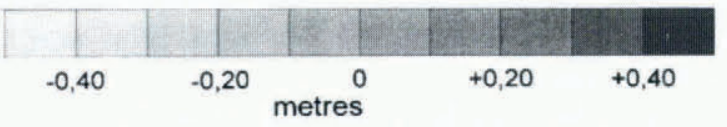

Fig. 5. Changes in the topography of the frontal area of Storglaciären, 1980-90, as measured from aerial photographs. The study area is indicated in Figure 2. Positive changes reflect sedimentation, and negative changes reflect erosion and/or subsidence. In order to reduce the details for presentation, a $10 \mathrm{~m}$ grid has been used instead of the $2 \mathrm{~m}$ grid actually employed in the calculations.

$630 \mathrm{~m}^{3}$ (Fig. 5). Some part of the volume gain may certainly be attributed to frost-heaving, especially at a newly exposed large till deposit in the centre of the area (Fig. 5). However, taking into consideration only areas which are affected by the meltwater streams, the annual volume of erosion by runoff from the surface corresponded to $\sim 1.0 \times 10^{3} \mathrm{~m}^{3}$, and sedimentation was $\sim 1.3 \times 10^{3} \mathrm{~m}^{3}$. These volumes are approximately $50 \%$ and $65 \%$ of the suspended-sediment load and $25-32 \%$ of the total transport (assuming a 50/50 ratio between measured suspended load and estimated bedload) measured in the water gauge at Rännan, $1 \mathrm{~km}$ downstream. The proglacial area acts as a large sediment-exchanger, in that fresh coarse sediments are deposited and old fine sediments are eroded from the surface.

In the ablation area of the glacier, the cold surface ice becomes impermeable to meltwater, and the permafrost in the ice can survive if melt rates are moderate. The radar soundings show a cold surface layer approximately $30 \mathrm{~m}$ thick. The glacier has a cold rim, about $100 \mathrm{~m}$ wide along the sides and $200 \mathrm{~m}$ at the front (Figs 2 and 4). It is likely that the ground underneath the toe of the glacier is frozen. 
Subglacial accumulation of till may occur where the bed is at the pressure-melting point for ice, but beneath cold ice and a frozen substrate there will be no sedimentation. The pattern of landforms in front of the tongue shows spatial similarities to the present temperature regime of the glacier, with loose fine-grained till and sediments in the centre, enclosed by a boulder-rich frozen zone. At present, permafrost seems to be thawing at the outer rim of the Holocene maximum glacier extent and to be developing in the deposit in the centre of the proglacial area (Fig. 5).

\section{CONGLUSIONS}

The measurements described suggest that the proglacial area of Storglaciären acts as a storage zone for sediments, and releases sediments to the proglacial stream. On average, there is an exchange of sediments of approximately $50 \%$ of the annual suspended-sediment load in the streams along the first kilometre from the glacier front. If the relation between bedload and suspended-sediment load is believed to be $50 / 50$, the mass exchange in front of Storglaciären is close to $30 \%$ of the total sediment transport. We may conclude that till- and sedimentcovered areas may cause significant errors when using flux in meltwater to assess the rate of subglacial erosion, though in this case the gain and loss of sediment within the area seem to be of the same amount. Photogrammetric studies are helpful tools in studies of massexchange processes within a proglacial area, and in studies of geomorphic changes within an area.

Moreover, the proglacial morphology suggests that the temperature distribution within the ice of an enlarged Storglaciären would be very similar to that of the present glacier. At present, permafrost is thawing in the area where the frozen toe of the glacier front used to be $80-90$ years ago. The central front area may originate from more temperate conditions where sediments were deposited when the glacier had a larger extent.

\section{ACKNOWLEDGEMENTS}

This project was financed by the Swedish Natural Science Research Council (NFR), and the Carl M:son Mannerfelt Foundation. Financial support was also given by Stockholm University and The Royal Institute of Technology in Stockholm. Nord-Optik AB supported us with geodetic equipment for the geodetic base survey. Thanks are due to C. Richardson, U. Hedman and J.-O. Näslund who helped us greatly during the field campaign. Thanks also to the Swedish Landsurvey Authority (LMV) which managed to photograph the area at the end of the cloudy summer of 1990. The figures were drawn by Mrs K. Weilow and $\mathrm{Mr}$ H. Drake. The language was improved by J. Boygle.

\section{REFERENCES}

Alexandersson, H. and B. Eriksson. 1989. Climate fluctuations in Sweden 1860-1987. Sieriges Meteorologiska och Hydrologiska Institut. Rapporter. Meteorologi och Klimalologi 58.

Björnsson, H. 1981. Radio-echo sounding maps of Storglaciären, Isfallsglaciären and Rabots glaciär, northern Sweden. Geogr. Ann., 63A $(3-4), 225-231$.

Eriksson, M., H. Björnsson, U. C. Herzfeld and P. Holmlund. 1993. The bottom topography of Storglaciären: a new map based on old and new ice depth measurements, analyzed with geostatistical methods. Stockholm, Stockholm University. Department of Physical Geography. (Forskningsrapport STOL-NG 95.

Hammer, K. M. and N.D. Smith. 1983. Sediment production and transport in a proglacial stream: Hilda Glacier. Alberta, Canada. Boreas, 12 2), $91-106$.

Hamran, S. -E., D. T. Gjessing, J. Hjelmstad and E. Aarholt. 1995. Ground penetrating synthetic pulse radar: dynamic range and modes of operation. J. Appl. Geophys., 33, 7-14.

Holmlund, P. 1987. Mass balance of Storglaciären during the 20th century. Geogr. Ann., 69A 3-4), 439447.

Holmlund, P. 1988. An application of two theoretical melt water drainage models on Storglaciären and Mikkaglaciären, northern Sweden. Geogr. Amn., 70A $1-2), 1-7$.

Holmlund, P. 1993. Surveys of post-Little Ice Age glacier fluctuations in northern Sweden. Z. Gletscherkd. Glazialgeol., 29 1), 1-13.

Holmlund, P. and M. Eriksson. 1989. The cold surface layer on Storglaciären. Geogr. Ann., 71A 3 -4), 241-244.

Holmlund, P., J. -O. Näslund and C. Richardson. In press. Radar surveys on Scandinavian glaciers, in search of useful climate archives. Geogr. Ann.

Hooke, R. LeB., J. E. Gould and J. Brzozowski. 1983. Near-surface temperatures near and below the equilibrium line on polar and subpolar glaciers. Z. Gletscherkd. Glazialgeol., 19 1), 125.

Karlén, W. 1973. Holocene glacier and climatic variations, Kebnekaise mountains, Swedish Lapland. Geogr. Ann., 55A 1), 29-63.

King, L. 1977. Permafrostuntersuchungen in Tarfala Schwedisch Lappland mit Hilfe der Hammerschlagseismik. Z. Gletscherkd. Glazialgeol., 12 2), 1976, 187-204.

King, L. 1982. Qualitative und quantitative Erfassungen von Permafrost in Tarfala Schwedisch-Lappland) und Jotunheimen (Norwegen) mit Hilfe geoelektrischer Sondierungen. Z. Geomorphol., Suppl., 43, $139-160$.

Ostrem, G. 1964. Ice-cored moraines in Scandinavia. Geogr. Ann., 46 3), 282-337.

Schneider, T. and C. Bronge. 1993. Suspended sediment transport and discharge of Tarfalajakk, the proglacial stream of Storglaciären, northern Sweden, 1980-1990. Stockholm, Stockholm University. Department of Physical Geography. (Forskningsrapport STOU-NG 94.

Schneider, T. and C. Bronge. In press. Suspended sediment transport in the Storglaciären drainage basin. Geogr. Ann.

Schytt, V. 1968. Notes on glaciological activities in Kebnekaise, Sweden during 1966 and 1967. Geogr. Ann., 50A 2), 111-120.

Seaberg, S. Z., J. Z. Seaberg, R. LeB. Hooke and D. W. Wiberg. 1988. Character of the englacial and subglacial drainage system in the lower part of the ablation area of Storglaciären, Sweden, as revealed by dye-trace studies. J. Glaciol., 34 117), 217-227.

Stenborg, T. 1969. Studies of the internal drainage of glaciers. Geogr. Ann., 51A $(1-2), 1341$.

Warburton, J. 1990. An alpine proglacial fluvial sediment budget. Geogr. Ann., $72 \mathbf{A} 3-4), 261272$. 